\title{
Analisis Kualitas Pemeriksaan Pengelolaan Keuangan Negara oleh Badan Pemeriksa Keuangan Republik Indonesia Perwakilan Sulawesi Selatan
}

\author{
${ }^{1}$ Dandi Darmadi, ${ }^{2}$ Rasyid Thaha \\ ${ }^{1}$ Prog. Studi Magister Ilmu Pemerintahan, Universitas Hasanuddin, Indonesia \\ ${ }^{2}$ Departemen Ilmu Politik dan Pemerintahan, Universitas Hasanuddin, Indonesia \\ Email : dandidarmadi138@gmail.com
}

Received: 20 Juni 2019; Revised: 28 Juni 2019; Accepted: 29 Juni 2019

\begin{abstract}
This study aims to analyze the quality of the examination of State Financial Management conducted by the Financial Examination Agency (BPK) of the Republic of Indonesia representative of South Sulawesi. Analyze how the criteria in giving opinion on regional finance so that the Opinion is in line with the findings of irregularities, besides how the results of the BPK's examination or findings can be used as a basis for law enforcement against the examinee if found to be a violation which is great for some parties. The method used in this research is descriptive type.. Qualitatively analyzed based on reports and records in the field. With data collection techniques including primary data, namely observation and interviews and secondary data, namely library research and documentation. The results of the study show that the audit process carried out by the BPK, namely, Planning, Implementation and Reporting of Examination, has a process that gives the entity a great opportunity to achieve WTP, namely the value of materiality which is quite tolerant and the number of meeting opportunities provided by the examiner and entity so that opportunity to commit fraud by negotiating so that the auditor does not contain findings. The advantage gained by the entity from the results of $B P K$ 's examination is getting trust from the community, obtaining Regional Incentive Funds and as a high selling point in political contestation.
\end{abstract}

Keywords: Regional finance; Government; BPK

\begin{abstract}
Abstrak
Penelitian ini bertujuan untuk menganalisis kualitas dari pemeriksaan Pengelolaan Keuangan Negara yang dilakukan oleh Badan Pemeriksa Keuangan (BPK) Republik Indonesia perwakilan Sulawesi Selatan. Menganalisa bagaimana kriteria dalam memberikan opini terhadap keuangan daerah sehingga Opini selaras dengan temuan penyimpangan yang diungkap oleh BPK, selain itu juga bagaimana hasil pemeriksaan atau temuan BPK dapat dijadikan dasar penegakan hukum terhadap terperiksa jika ditemukan ada pelanggaran serta dengan diperolehnya opini terbaik dari BPK akan menjadi keuntungan yang besar bagi beberapa pihak. Metode yang digunakan dalam penelitian ini adalah tipe deskriptif. Dianalisa secara kualitatif berdasarkan laporan dan catatan yang ada di lapangan. Dengan teknik pengumpulan data meliputi data primer yaitu observasi dan wawancara serta data sekunder yaitu studi kepustakaan dan dokumentasi. Dari Hasil penelitian menujukkan bahwa rangkaian proses pemeriksaan yang dilakukan BPK yaitu, Perencaanaan, Pelaksanaan dan Pelaporan Pemeriksaan terdapat proses yang memberi peluang besar entitas meraih WTP yaitu pada penetapan nilai materialitas yang cukup tinggi toleransinya serta banyaknya kesempatan pertemuan yang diberikan oleh prosedur antara pemeriksa dan entitas sehingga peluang untuk melakukan kecurangan dengan menegosiasikan agar auditor tidak memuat temuan. Keuntungan yang diperoleh oleh entitas dari hasil pemeriksaan BPK adalah mendapat kepercayaan dari masyarakat, memperoleh Dana Insentif Daerah dan sebagai nilai jual yang tinggi dalam kontestasi politik.
\end{abstract}

Kata kunci: Keuangan Daerah; Pemerintahan; BPK

Link DOI : http://dx.doi.org/10.31314/pjia.8.1.75-88.2019 


\section{PENDAHULUAN}

Komponen yang sangat penting dalam jalannya roda pemerintahan adalah adanya system keuangan yang dikelolah secara tertib sehingga menghasilkan kesejahteraan masyarakat yang diharapkan. Olehnya itu keuangan negara sangat diharapkan untuk dapat dikelola secara tertib sesuai dengan peraturan perundangundangan yang berlaku.

Laporan keuangan negara sebagai bentuk tanggung jawab kepada masyarakat agar dapat dipercaya maka diperlukan kualitas pemeriksaan laporan keuangan yang baik oleh Lembaga auditor yang independent sebagai elemen penting dalam menemukan berbagai pelanggaran entitas yang diperiksa dalam mengelola keuangannya. Kualitas hasil pemeriksaan merupakan kualitas kerja auditor yang ditunjuk dengan laporan hasil pemeriksaan yang dapat diandalkan berdasarkan standar yang telah ditetapkan.

Badan Pemeriksa Keuangan (BPK) berdasarkan Undang-Undang Nomor 15 tahun 2004 tentang Pemeriksaan Pengelolaan dan Tanggung Jawab Keuangan Negara pasal 2 ayat (2) Melaksanakan pemeriksaan atas pengelolaan dan tanggung jawab keuangan Negara, dan hasil dari pemeriksaan tersebut BPK memberikan opini terhadap pegelolaan keuangan daerah tersebut.

Kualitas tentang audit yang dilakukan oleh BPK terhadap Laporan keuangan banyak dipertanyakan, seperti kasus pada Serikat Pekerja Satuan Kerja Khusus Pelaksana Kegiatan Usaha Hulu Minyak dan Gas Bumi (SP SKK Migas) mempertanyakan kualitas temuan dan standar yang digunakan oleh auditor Badan Pemeriksa Keuangan (BPK).

Hal itu disampaikan menyusul dikeluarkannya laporan audit BPK terhadap SKK Migas tahun 2015 dengan hasil tidak wajar. Yang diduga terjadi inkonsistensi terhadap hasil akhir audit BPK. Pasalnya, materi yang menjadi temuan sama dengan temuan tahun-tahun sebelumnya, di mana hasil audit BPK menyatakan Wajar Tanpa Pengecualian, ditambah lagi temuan-temuan tersebut sudah ditindaklanjuti, diberi jawaban dan klarifikasi .

Selain hal tersebut diatas yang menyangkut kualitas pemeriksaan yang dilakukan oleh BPK juga ada pada persoalan antara pemberian opini dengan temuan penyalahgunaan anggaran, seperti pada kasus Kementrian Pemuda dan Olahraga (Kemenpora) tahun 2011 yang mendapat opini Wajar dengan Pengecualian (WDP), opini ini merupakan opini terbaik setelah WTP. Untuk opini WDP pada kemenpora ini dinilai bebas dari salah saji laporan keuangan meskipun ada ketidakwajaran dalam item tertentu, namun tidak memengaruhi kawajaran laporan keuangan secara keseluruhan.

Belakangan diketahui terjadi penyelewengan anggaran yang cukup signifikan di Kemenpora pada tahun buku 2010 - 2011. Hasil penyidikan KPK tahun 2013 menyimpulkan telah terjadi kerugian negara sebesar Rp 471 miliar dalam proyek pembangunan sarana olahraga terpadu di Hambalang Bogor yang dilaksanakan Kemenpora dalam kurun 2010 - 2011 .

Provinsi Sulawesi Selatanpun terjadi hal yang sama, pada tahun 2017 meraih predikat opini Wajar Tanpa Pengecualian (WTP), namun dalam Ikhtisar Hasil Pemeriksaan BPK penulis menemukan banyak materi temuan BPK terhadap pengelolaan keuangan Provinsi Sulawesi selatan ini, beberapa diantaranya adalah :

1. Sisa dana Program Gratis SPP di rekening virtual dan rekening penampungan senilai Rp9,34 miliar belum dikembalikan ke kas daerah. 
2. Kelebihan penyaluran dana BOS SMK dan SMA dan sisa dana BOS pada rekening penampungan dana BOS senilai Rp5,86 miliar belum dikembalikan ke kas daerah.

3. Sisa dana penyelenggaraan Program Pendidikan Gratis senilai Rp6,53 miliar tidak segera disetor ke kas daerah.

4. Pemprov Sulawesi Selatan belum memiliki pedoman terkait dengan penyelenggaraan bantuan keuangan pelayanan kesehatan gratis dan pedoman kerja pengelolaan investasi daerah belum ditetapkan berakibat ketidakjelasan pengelolaan investasi pemerintah daerah

Persoalan yang juga menjadi menarik bagi penulis adalah sinkronisasi hasil audit BPK dengan instansi pengakan hukum, terkait dengan hasil audit BPK dimana banyak kasus ketika BPK melakukan audit investigasi pada sebuah entitas tertentu dan BPK dari hasil investigasinya menyatakan terdapat pelanggaran aturan dan ditemui kerugian negara didalam pengerjaannya tapi hasil temuan tersebut terkadang diabaikan oleh penegak hukum, seperti yang diungkapkan oleh Anggota BPK, Ali Masykur Moesa bahwa $70 \%$ hasil audit temuan BPK diabaikan oleh aparat penegak hokum dan hanya sebagian kecil yang diproses yaitu sebanyak $30 \%$. Beberapa kasus yang bisa kita lihat terkait dengan masalah yang terjadi diatas seperti pada kasus temuan BPK terjadi kerugian negara Rp. 191,33 Miliar pada Pembelian Lahan RS Sumber waras namun temuan hasil investigasi BPK itu diabaikan oleh Komisi Pemberantasan Korupsi (KPK) dengan membuat pernyataan terbalik dari temuan BPK bahwa tidak ada pelanggaran hokum dalam kasus Sumber Waras.

Dalam Kasus yang sebaliknya bahwa hasil investigasi BPK yang menyatakan tidak terdapat pelanggaran aturan serta kerugian negara pada kasus tertentu namun tidak dijadikan acuan dalam penuntutan oleh Lembaga penegak hukum, seperti pada kasus Korupsi dana Haji Surya Darma Ali, dimana BPK menyatakan tidak menemukan kerugian keuangan negara dalam kasus korupsi dana haji 2010-2013 dan penyelewengan dana Operasional Menteri (DOM), namun itu tidak dipakai oleh pengadilan dan tetap menjerat yang bersangkutan.

Berdasarkan uraian yang telah dijelaskan sebelumnya maka ditetapkan rumusan masalah penelitian yaitu, Bagaimana proses pemeriksaan keuangan negara yang dilakukan oleh Badan Pemeriksa Keuang (BPK) untuk menghasilkan hasil pemeriksaan yang berkualitas dan Apa saja yang menjadi keuntungan serta kerugian bagi entitas terperiksa terhadap perolehan hasil pemeriksaan keuangan negara yang dilakukan oleh Badan Pemeriksa Keuangan (BPK) ?

\section{METODE PENELITIAN}

Tipe penelitian yang digunakan yakni deskriptif kualitatif, yaitu suatu penelitian yang bertujuan untuk memperoleh gambaran serta memahami dan menjelaskan bagaimana cara kerja atau pelaksanaan pemeriksaan keuangan negara yang dilakukan oleh sehingga menghasilkan pemeriksaan keuangan negara yang berkualitas. Menurut Bogdan dan Taylor dalam Lexy J (1996), metodologi kualitatif sebagai prosedur penelitian yang menghasilkan data deskriptif berupa kata-kata tertulis maupun lisan dari orang-orang dan perilaku yang dapat diamati.

Data yang terkumpul merupakan hasil dari lapangan yang diperoleh melalui pengumpulan data primer seperti Copyright (c) 2018, Publik : (Jurnal Ilmu Administrasi), ISSN: 2301-573X (Print), ISSN: 2581-2084 (Online) 
observasi, wawancara, studi pustaka, dan pengumpulan data sekunder seperi data pendukung yang diperoleh dari arsip/dokumen yang sudah ada atau literatur tulisan yang sangat berkaitan dengan judul penelitian.

Data yang terkumpul dianalisis secara deskriptif kualitatif dengan menguraikan dan menjelaskan melalui kata dan kalimat hasil penelitian yang diperoleh dalam bentuk data kuantitatif maupun kualitatif. Proses analisis data dilakukan melalui tahapan identifikasi menurut kelompok tujuan penelitian, mengelola dan menginterpretasikan data, kemudian dilakukan abstraksi, reduksi dan memeriksa keabsahan data.

\section{HASIL DAN PEMBAHASAN}

Berdasarkan UU 15 Tahun 2006 tentang BPK terdapat 3 jenis pemeriksaan yang berbeda yaitu Pemeriksaan Keuangan, Pemeriksaan Kinerja dan Pemeriksaan dengan Tujuan tertentu, ketiga jenis pemeriksaan tersebut memiliki perbedaan pada tujuan dan hasilnya.

Tabel 1. Perbedaan jenis Pemeriksaan

\begin{tabular}{|c|c|c|}
\hline $\begin{array}{c}\text { Jenis } \\
\text { Pemeriksaan }\end{array}$ & Tujuan & Hasil \\
\hline Kinerja & $\begin{array}{l}\text { Menilai aspek } \\
\text { ekonomi, } \\
\text { efisiensi, atau } \\
\text { efektivitas. }\end{array}$ & $\begin{array}{l}\text { Simpulan dan } \\
\text { rekomendasi } \\
\text { atas aspek } \\
\text { kinerja yang } \\
\text { dinilai. }\end{array}$ \\
\hline Keuangan & $\begin{array}{l}\text { Menilai } \\
\text { kewajaran } \\
\text { laporan } \\
\text { keuangan }\end{array}$ & $\begin{array}{l}\text { Opini atas } \\
\text { laporan } \\
\text { keuangan. }\end{array}$ \\
\hline PDTT & $\begin{array}{l}\text { Memberikan } \\
\text { simpulan } \\
\text { atas suatu hal } \\
\text { yang } \\
\text { diperiksa }\end{array}$ & $\begin{array}{l}\text { Tergantung } \\
\text { jenis PDTT } \\
\text {-Eksaminasi } \\
\text {-Review } \\
\text {-Agree upon } \\
\text { procedures }\end{array}$ \\
\hline
\end{tabular}

Sumber : Olahan Data Primer

Proses Pemeriksaan Keuangan oleh BPK
Proses pemeriksaan keuangan ini terdapat 3 langkah yaitu, perencanaan, pelaksanaan dan pelaporan hasil pemeriksaan.

\section{- Langkah Perencanaan}

Pemeriksaan harus direncanakan dengan sebaik-baiknya. Perencanaan pemeriksaan dilakukan untuk mempersiapkan program pemeriksaan yang akan digunakan sebagai dasar bagi pelaksanaan pemeriksaan sehingga pemeriksaan dapat berjalan secara efisien dan efektif. Berikut Langkah-langkah dalam perencanaan Pemeriksaan

\section{Pemahaman Tujuan Pemeriksaan dan Harapan Penugasan}

Pemahaman tujuan pemeriksaan dan harapan penugasan dilakukan untuk mengetahui hasil akhir dan sasaran pemeriksaan yang diharapkan pemberi tugas serta mengetahui kriteria pengukuran kinerja penugasan. Pemahaman tersebut dilakukan dengan melakukan komunikasi dengan pemberi tugas oleh pemeriksa dengan memperhatikan input-input sebagai berikut:

- Laporan hasil pemeriksaan tahun sebelumnya;

- Laporan hasil pemantauan tindak lanjut;

- Survei pendahuluan atas entitas atau objek yang baru pertama kali diperiksa;

- Database entitas;

- Hasil komunikasi dengan pemeriksa sebelumnya

Sedangkan Tujuan pemeriksaan keuangan adalah untuk memberikan keyakinan yang memadai (reasonable assurance) apakah Laporan Keuangan telah disajikan secara wajar dalam semua hal yang material, sesuai dengan prinsip akuntansi yang berlaku umum di Indonesia atau basis akuntansi komprehensif selain prinsip akuntansi yang berlaku umum di Indonesia dengan memperhatikan : 
Publik : (Jurnal Ilmu Administrasi) Vol 7 (1), Juni 2018

Keuangan dengan Standar Akuntansi;

2. Kecukupan pengungkapan;

3. Kepatuhan terhadap peraturan perundang-undangan;

4. Efektivitas sistem pengendalian intern.

\section{Pemenuhan Kebutuhan Pemeriksa}

Pemeriksa secara kolektif harus memiliki kecakapan profesional yang memadai untuk melaksanakan pemeriksaan, memenuhi persyaratan pendidikan berkelanjutan, dan memenuhi persyaratan kemampuan atau keahlian pemeriksa. Selain itu dalam semua hal yang berkaitan dengan pekerjaan pemeriksaan, organisasi pemeriksa, dan pemeriksa harus bebas dalam sikap mental dan penampilan dari gangguan pribadi, ekstern, dan organisasi yang dapat mempengaruhi independensi. Selain itu, pemeriksa yang melaksanakan pemeriksaan keuangan harus memenuhi kualifikasi tambahan, yaitu memiliki keahlian di bidang akuntansi dan pemeriksaan, memahami prinsip akuntansi yang berlaku umum yang berkaitan dengan entitas yang diperiksa, dan sebaiknya memiliki sertifikasi keahlian.

Dalam menyoal tentang kualitas pemeriksaan maka sangat erat kaitannya dengan Independensi dan kompetensi Auditor, mengutip Arum Ardianingsih (2018). Beliau menulis bahwa Kompetensi Auditor adalah tentang kemampuannya dalam menemukan pelanggaran terhadap entitas terperiksa, sedangkan Independensi adalah tentang kemauan auditor untuk mengungkapkan apa yang ditemukan. Berikut demografi auditor pada lingkup BPK Sulawesi Selatan.

\section{Tabel 2 Kondisi Auditor BPK Sulsel}

\begin{tabular}{lcc} 
Demografi & $\begin{array}{c}\text { Jumlah } \\
\text { Orang }\end{array}$ & $\begin{array}{c}\text { Persentase } \\
(\%)\end{array}$ \\
Jenis Kelamin & & \\
1. Laki-laki & 27 & 58,69 \\
2. Perempuan & 19 & 41,30 \\
& 23 & 50,00 \\
\hline Usia & 11 & 23,91 \\
1. 25-30 Th & 5 & 10,89 \\
2. 31-35 Th & 7 & 15,21 \\
3. 36-40 Th & & \\
4. 40 Th & 30 & 65,21 \\
Pendidikan & 16 & 34,78 \\
1. S1 & & \\
2. S2 & & \\
Lama & 23 & 50,00 \\
Bekerja & 13 & 28,26 \\
1. 0-5 Th & 8 & 17,39 \\
2. 6-10 Th & 2 & 4,34 \\
3. 11-15 Th & \\
4. > 15 Th & & \\
\hline
\end{tabular}

Sumber : Olahan Data Primer

\section{Independensi}

Jika melihat independensi auditor pada BPK Sulawesi selatan yang dianalisis berdasarkan konsep Lanvin (1976) dalam Supriyono (1988) independensi auditor dipengaruhi oleh faktor-faktor sebagai berikut:

1. Ikatan keuangan dan usaha dengan klien

2. Jasa-jasa lain selain jasa audit yang diberikan klien

3. Lamanya hubungan kantor akuntan publik dengan klien

Dari hasil penelitian yang dilakukan oleh Wahid Hasyim (2013) pada BPK Sulawesi Selatan mengungkapkan bahwa independensi dan kompetensi berpengaruh terhadap kualitas audit.

a). Ikatan kepentingan keuangan dan hubungan usaha dengan klien

Ikatan keuangan dan hubungan usaha dengan klien di antaranya selama periode kerja yaitu auditor atau kantornya memiliki kepentingan keuangan langsung atau tidak langsung yang material di dalam perusahaan yang menjadi kliennya. Untuk 
poin ini tidak ditemukan dalam kaitannya dengan auditor BPK sebagai orang yang melaksanakan pemeriksaan dengan memperoleh gaji dari negara, berbeda dengan kantor akuntan swasta yang dimana dibayar oleh pembeli jasanya dalam melakukan audit sebuah perusahaan.

Sehingga sangat memengaruhi independensi auditor. Penelitian yang dilakukan oleh Ika dan Wibowo (2011), Yanthi, dkk (2012), dan Dahlan, dkk (2012) menemukan adanya pengaruh negatif antara ikatan kepentingan keuangan terhadap independensi auditor.

\section{b). Jasa-Jasa Lain selain jasa audit yang diberikan klien}

Pelayanan jasa selain jasa audit akan menciptakan hubungan kerja antara auditor dan klien yang terlalu dekat dan akun tunduk pada tekanan klien. Ika dan Wibowo (2011) serta Dahlan, dkk (2012) menyimpulkan bahwa pemberian jasa selain jasa audit memberikan pengaruh negitif terhadap independensi auditor.

BPK sebagai Lembaga negara yang independent tidak memiliki tugas lain yang diamanatkan oleh UU selain melakukan pemeriksaan.

\section{c). Lamanya hubungan kantor akuntan publik dengan klien}

Lamanya hubungan audit dianggap dapat membuat auditor tidak melaksanakan tugasnya sesuai etika profesi yang berlaku. Ketika hubungan antara auditor dengan klien semakin panjang, maka ketergantungan keuangan auditor terhadap klien semakin besar. Semakin tingginya ketergantungan auditor, maka dikhawatirkan independensi auditor semakin menurun karena auditor akan tunduk pada tekanan klien.

Apabila auditor tunduk dengan tekanan klien maka konsekuensi perilaku mereka dalam melaksanakan tugasnya akan tidak dilandasi tanggung jawab.
Logika ini yang mendorong untuk melarang auditor memiliki hubungan yang panjang dengan klien. Penelitian yang dilakukan oleh Ika dan Wibowo (2011), Ahmad, dkk (2012), dan Kasidi (2007) menyatakan bahwa lamanya hubungan audit (Tenure of audit) berpengaruh secara negatif terhadap independensi. Hal ini dimaksudkan karena semakin lama hubungan kerja auditor dengan klien, maka akan memunculkan suatu fenomena saling membutuhkan, sehingga hal ini berbahaya bagi pengambilan keputusan audit.

Dalam sistem kepegawaian BPK dari hasil wawancara yang dilakukan penulis menemukan bahwa auditor BPK akan sulit menjalin hubungan lama dnegan klien karena mereka hanya diberikan kesempatan memeriksa satu entitas satu periode pemeriksaan saja, seperti di Sulawesi selatan, auditor di rolling untuk melakukan pemeriksaan pada tiap-tiap kabupaten/kota, setelah auditor tersebut menyelasaikan seluruh kabupaten/kota, maka dipindahkan ke perwakilan lain lagi.

\section{Kompetensi}

Salah satu faktor personal dalam diri seorang auditor adalah keahlian atau kompetensi auditor. Dalam standar audit disebutkan bahwa audit harus dilaksanakan oleh seorang atau lebih yang memiliki keahlian dan pelatihan teknis yang cukup sebagai seorang auditor. Seorang auditor yang memiliki keahlian atau kompetensi yang memadai akan lebih memahami dan mengetahui berbagai masalah secara lebih mendalam dan lebih mudah mengikuti perkembangan yang semakin kompleks dalam lingkungan audit yang terdapat dalam objek yang diauditnya.

Menurut Shanteau dalam Mayangsari (2003), kompetensi auditor merupakan keahlian audit yang dimiliki oleh seorang auditor untuk mencapai tujuan audit 
dengan baik. Memiliki kemampuan berpikir untuk mengumpulkan, mengolah serta menganalisa informasi. Memiliki karakterisitik kemampuan berpikir untuk beradaptasi dengan situasi yang baru serta mengabaikan atau menyaring informasi yang tidak relevan. Kompetensi melibatkan proses berkesinambungan antara pendidikan, pelatihan, dan pengalaman.

Perihal auditor BPK Sulawesi Selatan kompetensi masih diakui menjadi permasalahan baik dari segi jumlah auditor yang masih kurang, serta tingkat pengalaman kerja yang kurang, sehingga dalam proses pemeriksaan auditor muda lebih banyak dilibatkan, sekalipun tetap akan diawasi oleh auditor senior. Diungkapkan juga bahwa pemeriksaan yang dilakukan tidak hanya melibatkan akuntan, tetapi Auditor dengan latar belakang IT jika entitas memiliki sistem yang terintegrasi dengan teknologi.

\section{Pemahaman Atas Entitas Terperiksa}

Pemahaman atas entitas bertujuan untuk mendapatkan pemahaman yang lebih dalam mengenai proses kerja secara umum dan risiko terkait dari tiap proses kerja spesifik entitas yang diperiksa, dan untuk mengidenfikasikan dan memahami hal-hal penting yang harus dipenuhi oleh entitas dalam mencapai tujuan.

Dalam tahapan ini penulis menganalisis dapat cacatnya indpendensi auditor dikarenakan untuk memperoleh gambaran tentang entitas terperiksa maka auditor diberi ruang untuk mendiskusikan hal tersebut dengan top manajemen entitas tersebut, yang seharusnya pemeriksa yang bebas dari segala pengaruh harus menjauhkan diri dari segala bentuk upaya yang bias memancing pengaruh tersebut.

\section{Pemantauan Tindak Lanjut Hasil Pemeriksaan Sebelumnya}

Tujuan dari tahap ini adalah mengidentifikasi tindak lanjut saran/rekomendasi BPK, menilai Copyright @ 2018, Publik : (Jurnal Ilmu Administrasi), ISSN: 2301-573X (Print), ISSN: 2581-2084 (Online) pelaksanaan tindak lanjut atas rekomendasi BPK, apakah telah sesuai dengan rekomendasi tersebut atau tidak dan mengidentifikasi dampaknya pada pelaporan keuangan yang diperiksa. Pelaksanaan tindak lanjut mungkin dapat pula mengindikasikan adanya risiko lain yang masih harus diperhatikan dalam pemeriksaan tahun berjalan. Pemeriksa harus menyadari akan kemungkinan ini terhadap risiko pemeriksaan yang dilakukan.

Kekurangan dan perbaikan yang diidentifikasikan dalam proses tindak lanjut harus dilaporkan. Pelaporan tindak lanjut dapat berdiri sendiri atau dikompilasikan dengan hasil pemeriksaan tahun berjalan (sebagai temuan pemeriksaan). Dokumentasi pemantauan tindak lanjut dimuat dalam Formulir Pemantauan Tindak Lanjut. Rekomendasi signifikan atas hasil pemeriksaan tahuntahun sebelumnya yang tidak atau belum seluruhnya ditindaklanjuti harus menjadi bahan pertimbangan atas pemeriksaan tahun berjalan. Jika ditemukan pelanggaran dalam Laporan keuangan entitas terperiksa maka akan diberikan waktu 60 hari untuk melakukan perbaikan.

Melihat pertimbangan diatas dimana jika dalam pemeriksaan berjalan masih ditemukan ada tindak lanjut yang belum dilaksanakan atau belum selesai maka sangat potensi untuk menjadi dasar pemberian opini terhadap laporan keuangan terperiksa. Namun di Provinsi Sulawesi Selatan pada Tahun 2017 Meraih Opini Wajar Tanpa Pengecualian (WTP), sedangkan masih banyak temuan-temuan yang belum ditindak lanjuti oleh Pemerintah Provinsi Sulawesi Selatan, seperti pada data tabel 3 . 
Available Online at http://journal.umgo.ac.id/index.php/Publik

Publik : (Jurnal Ilmu Administrasi) Vol 7 (1), Juni 2018

Tabel 3 Rekomendasi BPK Akumulasi 2014-2017 untuk Pemprov Sulsel

\begin{tabular}{lc}
\hline Jmlh Rekomendasi & 1268 \\
& $($ Rp. 130,86 M) \\
\hline Telah ditindaklanjuti & 794 \\
Belum selesai & (Rp. 56,06 M) \\
ditindaklanjuti & 397 \\
Belum & (Rp. 69,71 M) \\
ditindaklanjuti & 72 \\
Tidak dapat & (Rp. $3,67 \mathrm{M})$ \\
ditindaklanjuti & 5 \\
\hline
\end{tabular}

Sumber: Biro Hukum Pemprov Sulsel

Dalam Penentuan pemberian opini terhadap Laporan Keuangan sangat memperhatikan tindak lanjut yang dilaksanakan oleh entitas terperiksa atas temuan sebelumnya, tindak lanjut tersebut dapat dilaporkan tersendiri dan dapat juga dikompilasikan dengan laporan pemeriksaan yang berjalan. Jika tindak lanjut temuan sebelumnya belum dikerjakan atau belum selesai dikompilasikan dengan laporan pemeriksaan yang berjalan maka tidak akan mungkin meraih opini WTP.

\section{Penetapan Materialitas Awal dan Kesalahan Tertoleransi}

Materialitas merupakan besaran penghilangan atau kesalahan pencatatan yang sangat memengaruhi pengambilan keputusan. Pemeriksa juga menentukan jumlah nominal yang tepat untuk digunakan dalam mempersiapkan batas nominal jurnal koreksi yang akan diajukan. Misalnya, dalam suatu dokumentasi koreksi pemeriksaan (Summary of Audit Differences). Penilaian materialitas awal dilaksanakan melalui pekerjaan perencanaan pemeriksaan, khususnya pada saat pemeriksa menilai kembali penilaian risiko secara gabungan atau pada saat pemeriksa mengidentifikasi beberapa koreksi hasil pemeriksaan.

Dasar penetapan materialitas yang dapat digunakan oleh Pemeriksa adalah sebagai berikut: a. total pendapatan atau total belanja, untuk entitas nirlaba. Contoh: Pemerintah Pusat, Lembaga Negara, dan Pemerintah Daerah mempunyai jumlah total pendapatan atau total belanja yang besar sehingga dasar penetapan materialitas lebih tepat didasarkan pada total pendapatan atau total belanja;

b. laba sebelum pajak atau pendapatan, untuk entitas yang bertujuan mencari laba. Contoh: BUMN, BUMD, dan BLU, merupakan lembaga pemerintah yang bertujuan mencari laba sehingga penentuan dasar materialitas lebih tepat menggunakan laba sebelum pajak; dan

c. nilai aset bersih atau ekuitas, untuk entitas yang berbasis aset. Contoh: meskipun sebagian besar pemeriksaan atas LKKL/LKPP dan LKPD menggunakan total penerimaan atau total belanja sebagai dasar penetapan materialitas, terdapat pemeriksaan atas LKKL, seperti Kementerian XYZ, yang lebih tepat menggunakan dasar aset dalam menetapkan batas materialitas karena jumlah aset dalam Kementerian tersebut sangat signifikan dan menjadi perhatian utama bagi pembaca laporan keuangan dan pengambil keputusan.

Pada Pemerintah Provinsi Sulawesi Selatan sendiri yang meraih opini pada tahun 2016 adalah Wajar Tanpa Pengecualian (WTP) maka pada pemeriksaan tahun 2017 ditetapkan Nilai materialitas sebesar 3\%. Total Belanja 2017 Sulsel adalah Rp. 9.898.600.069.886,00, jadi nilai Materialitasnya adalah 296 Miliar. Meskipun BPK Perwakilan Sulsel mengungkapkan ada temuan, namun hal tersebut tidak melebihi nilai material yang ditetapkan.

Apabila terdapat suatu transaksi atau akun yang mengandung pelanggaran terhadap peraturan meskipun nilai 
nominalnya kecil, transaksi atau akun tersebut harus tetap menjadi temuan pemeriksaan terutama yang berdampak terhadap opini pemeriksaan. Sebagai contoh : Pajak tidak disetor sebesar 500.000.000,00, nilai tersebut dibawah nilai TM tetapi dari sisi kualitatif sangat material karena sifat pajak yang harus disetor berapapun nominalnya. Oleh karena itu, akun pajak harus menjadi temuan pemeriksaan dan menjadi salah satu pertimbangan untuk menentukan opini pemeriksaan.

Dalam tahap perencanaan pemeriksaan keuangan yang dilaksanakan oleh BPK dapat terlihat begitu kompleksnya formulasi yang harus ditetapkan namun dalam beberapa tahapan dimana indpendensi auditor dipertaruhkan, beberapa diantaranya seperti pada tahap perencanaan pemeriksaan maka auditor diberi ruang untuk berdiskusi dengan Top Management suatu entitas tentang kondisi entitas terperiksa tersebut, kemudian pada aspek nilai materialitas yang masih ditoleransi, meskipun Informan penelitian mengungkapkan bahwa pentingnya nilai materialitas karena ada batasan nilai yang akan berdampak pada kinerja atau pengambilan keputusan, namun bagaimanapun itu upaya mewujudkan pemerintahan dengan tata kelola yang baik dan bersih harus tetap dijunjung dengan mempersempit area toleransi terhadap pelanggaran yang terjadi jika tidak maka akan menimbulkan ketidakjeraan oleh suatu entitas

\section{- Langah Pelaksanaan Pemeriksaan}

Pelaksanaan pemeriksaan merupakan realisasi atas perencanaan pemeriksaan yang telah ditetapkan sebelumnya.

1. Pelaksanaan Pengujian Analitis Terinci.

Melalui pengujian analitis terinci ini, diharapkan pemeriksa dapat menemukan hubungan logis penyajian antara masingmasing akun/perkiraan pada laporan keuangan. Di samping itu, pemeriksa dapat menilai kecukupan pengungkapan atas setiap perubahan pada pos/akun/unsur pada laporan keuangan yang diperiksa serta menentukan area-area signifikan dalam pengujian sistem pengendalian intern dan pengujian substantif atas transaksi dan saldo.

2. Pengujian Sistem Pengendalian Intern

Pengujian terhadap sistem pengendalian intern meliputi pengujian yang dilakukan pemeriksa terhadap efektivitas desain dan implementasi sistem pengendalian intern. Dalam pengujian desain system pengendalian intern, pemeriksa mengevaluasi apakah system pengendalian intern telah didisain secara memadai dan dapat meminimalisasi secara relatif salah saji dan kecurangan. Sementara itu, pengujian implementasi sistem pengendalian intern dilakukan dengan melihat pelaksanaan pengendalian pada kegiatan atau transaksi yang dilakukan oleh pihak yang terperiksa.

3. Pengujian Substantif Atas Transaksi dan Saldo Akun

Pengujian ini meliputi pengujian subtantif atas transaksi dan saldo akun/perkiraan serta pengungkapannya dalam laporan keuangan yang diperiksa. Pengujian tersebut memerhatikan kesesuaian dengan standar akuntansi pemerintahan, kecukupan pengungkapan, efektivitas sistem pengendalian intern, dan kepatuhan terhadap peraturan perundangundangan. Pengujian subtantif atas transaksi dan saldo dilakukan setelah pemeriksa memperoleh laporan keuangan entitas yang diperiksa. Pengujian subtantif atas transaksi dan saldo dapat juga dilakukan pada pemeriksaan interim, tetapi hasil pengujian tersebut perlu direview lagi setelah laporan keuangan diterima.

4. Penyelesaian Penugasan 
Pemeriksa perlu mereviu kembali kontrak/ komitmen jangka panjang yang dibuat entitas terkait dengan kemungkinan kerugian yang mungkin terjadi dari kontrak/komitmen tersebut.Pemeriksaan kontrak/komitmen tersebut dapat dilakukan ketika pemeriksa melakukan pemeriksaan atas transaksi dan saldo akun terkait. Namun, prosedur reviu kontrak/komitmen dimaksudkan untuk menentukan kemungkinan kerugian yang akan terjadi. Untuk itu, pemeriksa perlu mereviu kembali perjanjian/kontrak atau komitmen lainnya yang bersifat jangka panjang. Apabila dalam hasil reviu ditemukan kemungkinan kerugian yang akan terjadi dan bersifat material terhadap laporan keuangan, pemeriksa segera mungkin manginformasikan kepada entitas yang diperiksa tentang perlunya membuat addendum kontrak untuk menghindari kerugian yang lebih besar.

5. Penyusunan Konsep Temuan Pemeriksaan

Konsep Temuan Pemeriksaan (TP) atas laporan keuangan entitas yang diperiksa merupakan permasalahan yang ditemukan oleh pemeriksa yang perlu dikomunikasikan kepada pihak yang terperiksa. Permasalahan tersebut meliputi: (1) ketidakefektivan system pengendalian intern, (2) kecurangan dan penyimpangan dari ketentuan peraturan perundangundangan, (3) ketidakpatuhan terhadap peraturan perundang-undangan yang signifikan, dan (4) ikhtisar koreksi. Konsep TP disusun oleh anggota tim atau ketua tim pada saat pemeriksaan berlangsung. Konsep TP yang disusun oleh anggota tim harus direviu oleh ketua tim.

Apabila tim pemeriksa menemukan indikasi Tindak Pidana Korupsi (TPK) dalam tahap ini, ketua tim segera melaporkannya kepada pengendali teknis. Indikasi TPK tersebut dilaporkan oleh pengendali teknis kepada penanggung jawab untuk dilaporkan kepada pemberi tugas. Penanganan lebih lanjut indikasi temuan TPK mengacu pada PMP dan tata cara penyampaian temuan indikasi TPK kepada pihak berwenang mengacu pada kesepakatan bersama BPK dan Kejaksaan Agung RI.

Konsep TP tersebut disampaikan ketua tim pemeriksa kepada pejabat entitas yang berwenang untuk mendapatkan tanggapan tertulis dan resmi dari entitas tersebut. Tim pemeriksa dapat melakukan diskusi dengan pimpinan entitas yang diperiksa setelah pemberian TP untuk ditanggapi. Diskusi dilaksanakan untuk klarifikasi atas permasalahan yang diungkap dalam konsep TP dan relevansi tanggapan dari entitas. Entitas yang diperiksa dapat menyampaikan data/informasi terkait dengan permasalahan yang diungkap dalam TP. Apabila data/informasi yang disampaikan oleh entitas membuktikan analisis dalam TP salah dan diakui oleh tim pemeriksa, maka konsep TP dinyatakan batal (drop). Apabila data/informasi yang disampaikan oleh entitas yang diperiksa tidak dapat membuktikan kesalahan penganalisisan dalam konsep TP, maka konsep TP dinyatakan menjadi TP final.

\section{- Langkah Pelapoan Hasil Pemeriksaan}

Hasil pelaksanaan pemeriksaan yang dilakukan oleh pemeriksa dituangkan secara tertulis ke dalam suatu bentuk laporan yang disebut dengan Laporan Hasil Pemeriksaan (LHP). LHP merupakan bukti penyelesaian penugasan bagi pemeriksa yang dibuat dan disampaikan kepada pemberi tugas, yakni Badan.

\section{Penyusunan Konsep LHP}

Jenis LHP Keuangan atas Laporan Keuangan terdiri atas : 
a. LHP atas Laporan Keuangan; Laporan atas Kepatuhan;

b. Laporan atas Pengendalian Intern.

Pemeriksa dapat menyampaikan laporan tambahan sesuai dengan kebutuhan. Contoh: pemeriksa dapat menyampaikan hasil analisis transparansi fiskal pada pengelolaan dan tanggung jawab keuangan negara

2. Penyampaian Konsep LHP kepada Entitas

Konsep LHP yang telah disetujui penanggung jawab harus disampaikan kepada pimpinan entitas sebelum batas akhir waktu penyampaian laporan keuangan yang telah diperiksa sesuai ketentuan yang berlaku bagi entitas. Penyampaian konsep LHP tersebut harus mempertimbangkan waktu bagi entitas untuk melakukan pemahaman dan pembahasan Bersama dengan BPK dan proses penyelesaian LHP secara keseluruhan sebelum batas akhir waktu penyampaian laporan keuangan yang telah diperiksa sesuai ketentuan yang berlaku bagi entitas. Konsep LHP yang disampaikan telah berisi opini hasil pemeriksaan dan saran-saran untuk temuan kepatuhan terhadap peraturan perundangundangan dan efektivitas pengendalian intern.

3. Pembahasan Konsep LHP dengan

Pejabat Entitas yang Berwenang

Konsep LHP yang telah disetujui penanggung jawab dibahas Bersama dengan pimpinan entitas yang diperiksa. Pembahasan konsep LHP dengan pejabat entitas yang diperiksa diselenggarakan oleh penanggung jawab dan dilakukan untuk (a) membicarakan kesimpulan hasil pemeriksaan secara keseluruhan, dan (b) kemungkinan tindak lanjut yang akan dilakukan. Pembahasan konsep LHP dilakukan di kantor Badan Pemeriksa Keuangan atau di kantor pusat entitas yang diperiksa atau dalam bentuk lainnya. Copyright @ 2018, Publik : (Jurnal Ilmu Administrasi), ISSN: 2301-573X (Print), ISSN: 2581-2084 (Online)
4. Penyusunan Konsep Akhir dan Penyampaian LHP

Berdasarkan hasil pembahasan atas konsep LHP tersebut, tim pemeriksa menyusun konsep akhir LHP. Konsep akhir tersebut disupervisi oleh pengendali teknis dan ditandatangani oleh penandatangan LHP. Penanggung jawab pemeriksaan bersama dengan pengendali teknis, dan ketua tim membahas konsep akhir LHP laporan keuangan. Selanjutnya konsep akhir LHP tersebut dibahas bersama penanggung jawab dan Anggota Badan untuk mendapatkan arahan dan persetujuan. Setelah mendapatkan persetujuan, LHP atas laporan keuangan ditandatangani oleh Badan/kuasanya yang memenuhi syarat.

Serangkaian pemeriksaan yang dilaksanakan oleh BPK hasil analisis penulis masih membuka peluang terjadi fraud (kecurangan) sehingga kualitas pemeriksaan dipertaruhkan. Seperti yang diungkapkan oleh Hendra dkk (2014) dalam penelitiannya tentang teori Fraud Triangle yang dikembangkan oleh Donald R. Cressey (1953), mengatakan bahwa fraud atau kecurangan disebabkan oleh tiga faktor, yaitu: (1) Pressure atau tekanan, (2) Opportunity atau peluang, Rationalization atau pembenaran. Opportunity adalah peluang yang memungkinkan fraud terjadi. Biasanya disebabkan karena internal control suatu organisasi yang lemah, kurangnya pengawasan, dan penyalahgunaan wewenang.

Pada pelaksanaan pemeriksaan keuangan oleh BPK sangat menjunjung tinggi nilai independensi yang artinya bebas dari segala pengaruh dan menjauhkan diri dari segala bentuk terbukanya peluang dipengaruhi, akan tetapi dalam pelaksanaan pemeriksaan oleh BPK memberi banyak ruang terhadap munculnya kesempatan untuk terjadi Fraud 
atau kecurangan, hal ini dikarenakan salah satunya ketika temuan akan ditetapkan maka dilakukan pembahasan terlebih dulu dengan pimpinan entitas terperiksa, hal inilah yang sangat membuka peluang terjadinya kecurangan.

Di antara 3 elemen fraud triangle, opportunity merupakan elemen yang paling memungkinkan untuk diminimalisir melalui penerapan proses, prosedur, kontrol dan upaya deteksi dini jika secara betul-betul dilaksanakan.

\section{Temuan BPK sebagai Bahan Penegakan Hukum}

Setiap semester Badan Pemeriksa Keuangan (BPK) telah melaporkan hasil temuannya yang mengandung unsur tindak pidana korupsi ke aparat penegak hukum. Bagi kejaksaan, hasil temuan BPK merupakan pintu masuk untuk mengungkap ada atau tidaknya suatu tindak pidana korupsi.

Sebab unsur pidana jelas tidak terdapat di dalam hasil temuan BPK. Unsur pidana itu hanya dapat dilihat dalam suatu rangkaian dari proses persesuaianpersesuaian bukti-bukti seperti keterangan saksi, ahli, surat, petunjuk, keterangan terdakwa dan lain-lainnya sebagaimana diatur dalam undang-undang. Berdasarkan Pasal 30 Undang-Undang Nomor 16 Tahun 2004 tentang Kejaksaan Republik Indonesia, yaitu:

"Kejaksaan berwenang untuk melakukan penyidikan terhadap tindak pidana teretntu berdasarkan undang-undang"

Dalam Penjelasan Umum UndangUndang Nomor 16 Tahun 2004 lebih lanjut dijelaskan bahwa kewenangan kejaksaan untuk melakukan penyidikan tindak pidana tertentu dimaksudkan untuk menampung beberapa ketentuan yang memberikan kewenangan kepada Kejaksaan untuk melakukan penyidikan dibatasi pada tindak pidana tertentu yaitu yang secara spesifik diatur dalam Undang-Undang.

Sedangkan mekanisme tindak lanjut temuan dari BPK, yaitu Kejaksaan akan terlebih dahulu mempelajari isi pengaduan ataupun laporan dari BPK tersebut. Selanjutnya dilakukan penyidikan dalam rangka mencari dan menemukan bukti suatu peristiwa yang diduga sebagai tindak pidana pidana. Hal ini dilakukan untuk menentukan apakah kasus tersebut dapat dilakukan penyidikan menurut cara yang tentunya didasarkan kepada peraturan perundang-undangan dan SOP. Apabila terjadi suatu tindak pidana, maka akan dilihat apakah tindak pidana yang terjadi, masuk dalam lingkup kewenangan Kejaksaan atau tidak. Apabila dalam lingkup kewenangan kejaksaan akan dilanjutkan ke tahap penyidikan. Namun bila bukan dalam lingkup kewenangan Kejaksaan, seperti tindak pidana umum, pajak dan lain-lain maka, peristiwa hukum tersebut akan diserahkan pada pihak yang berwenang.

Setiap hasil temuan BPK merupakan pintu masuk untuk mengungkap ada atau tidaknya suatu tindak pidana. Jadi unsur pidana jelas tidak terdapat di dalam hasil temuan BPK. Sebab unsur pidana hanya dapat dilihat dalam suatu rangkaian persesuaian-persesuaian bukti-bukti seperti keterangan saksi, ahli, surat, petunjuk, keterangan terdakwa dan lain-lain sebagaimana diatur dalam peraturan undang-undang di luar KUHAP. Hasil pemeriksaan BPK dapat dijadikan sebagai bukti awal dalam melakukan penyelidikan terhadap kasus korupsi. Kejaksaan tentunya akan menindaklanjutinya dengan melakukan penyelidikan untuk mencari dan menemukan suatu peristiwa yang diduga mengandung unsur tindak pidana 
guna menemukan dapat atau tidaknya dilakukan penyidikan.

Bagi Kejaksaan dalam pelaksanaan pemberantasan dan tentunya harus mengacu pada peraturan perundangundangan. Hal itu dimaksudkan agar terpenuhi unsur-unsur tindak pidana sebagaimana termuat dalam KUHAP dan Undang-Undang Pemberantasan Tindak Pidana Korupsi. Karenanya, seluruh bukti permulaan yang nantinya akan menjadi alat bukti yang mendukung terpenuhinya unsur-unsur tindak pidana dari si pelaku secara maksimal dan bukan hanya satu atau dua alat bukti melainkan keseluruhan alat bukti yang saling bersesuaian satu dengan yang lainnya. Secara umum, pengumpulan bukti-bukti tersebut bukan hanya sekadar bukti-bukti, melainkan harus saling bersesuaian antara satu dengan yang lainnya. Dengan demikian Kejaksaan ketika mendapatkan laporan terkait kasus korupsi tentunya sebelum mencari, menemukan dan mengumpulkan buktibukti harus dari awal memahami jenis dan pola dari sebuah kasus dugaan korupsi.

\section{PENUTUP}

\section{Kesimpulan}

BPK sebagai Lembaga pemeriksa keuangan negara menjalankan proses Pemeriksaan terhadap entitas dengan 3 tahap pemeriksaan, yaitu Perencanaan, Pelaksanaan dan Pelaporan hasil Pemeriksaan. Kualitas pemeriksaan juga sangat dipengaruhi oleh Independensi dan kompetensi yang dimiliki oleh auditor. Kualitas dari pelaksanaan pemeriksaan yang dilakukan oleh BPK masih sangat rentan terhadap peluang untuk berbuat kecurangan hal tersebut ditandai dengan banyaknya ruang diskusi bagi entitas dan pemeriksa, bahkan sebelum temuan tersebut difinalkan maka pemeriksa tetap akan meminta terlebih dahulu penjelasan dari entitas terperiksa. Keuntungan yang diperoleh oleh entitas dari predikat WTP yang diberikan oleh BPK diantaranya mendapat Dana Insentif Daerah (DID), nilai jual buat investor, serta memberikan nilai positif bagi petahana dalam kontestasi politik selanjutnya.

\section{Saran}

Diharapkan laporan penelitian ini memberikan kontribusi positif bagi BPK sebagai Lembaga pemeriksa keuangan negara menjalankan proses Pemeriksaan

\section{DAFTAR PUSTAKA}

Ali, Faried dan Andi Syamsu Alam. (2012). Studi Kebijakan Pemerintah. Bandung: Refika Aditama.

Ardianingsih, Arum. (2018). Audit Laporan Keuangan. Jakarta

Arens, A Alvin. (2014). Auditing And Assurance Services. Jakarta: Erlangga.

Arifin, Anwar. (2007). Public Relations .Jakarta: Pustaka Indonesia.

Halim, Abdul. (2012). Pengelolaan Keuangan Daerah. Yogyakarta: UPP STIM YKPN.

Ikbar, Yanuar. 2012. Metode Penelitian Sosial Kualitatif. Bandung: Refika Aditama.

L.M. Samryn. (2014). Pengantar Akuntansi. Jakarta: Rajawali Pres

Robbins,Stephen, dan Mary Coulter. (2010). Manajemen. Jakarta: Erlangga

Saidi, Djafar. (2014) .Hukum Keuangan Negara. Jakarta: Raja Grafindo

Suharso dan Ana Retnoningsih. (2011). Kamus Besar Bahasa Indonesia. Semarang: Widya Karya.

Subarsono. (2005). Analisis Kebijakan Publik. Yogyakarta: Pustaka Peajar.

Syafiie, Inu Kencana. (2013) Ilmu Pemerintahan. Jakarta: Bumi Aksara 
Available Online at http://journal.umgo.ac.id/index.php/Publik

Publik : (Jurnal Ilmu Administrasi) Vol 7 (1), Juni 2018

Tarigan, Anderiasta. (2014). Memahami

Ilmu Pemerintahan. IPDN PRESS.

Jatinangor.

Thoha, Miftah. (2012). Birokrasi dan politik Indonesia. Jakarta: Raja Grafindo.

Tugiman, Hiro. (2006). Standar

Profesional Audit Internal. Jakarta:

Kanisius 